\title{
O quintal da minha casa
}

\section{AURÉLIO MICHILES}

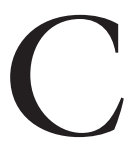

OM UM SORRISO diabólico ele diz ao iniciar o filme: "Tudo o que vocês virem na hora seguinte é absolutamente verdadeiro" "E o que acontece depois nos lança para sempre na indagação sobre o que é documentário ou ficção. Um dilema que surge desde a invenção do cinema. Encorajado por essa premissa, vou com a cara e a coragem penetrar nessa selva escura, e pouco me importa que eu me perca. Como um seringueiro, estarei carregando uma poronga na testa assobiando feito um mantra aquele samba que diz, "quem acha, vive se perdendo". Sob efeitos atonais, relâmpagos, trovões, recorrências de imagens, fotogramas, diálogos, livros, fotos, pinturas, desenhos, cartazes de filmes aparecem como partes de um sonho. Com gestos iconoclastas aposso-me dessas imagens, dando-lhes novos significados e metáforas. Um desafio semelhante àqueles sentimentos de quando íamos assistir aos filmes proibidos a menores de catorze anos, num exercício fascinante de transgressão, sob a atmosfera de luz e sombras. Aqui e ali minha sombra se agiganta ou se esconde por entre a folhagem da selva, a certeza da minha caminhada é a busca de um personagem para o documentário: O quintal da minha casa. Ele pretende refletir sobre o morar do homem no Amazonas, mas num recorte onde possa incluir a vivência pessoal, algo onde o documentário faça como o movimento das águas dos rios Negro e Solimões, que parecem ser diferentes e, no entanto, integram a mesma paisagem e o mesmo destino, o caminho do mar. Encontro-me com a poronga na cabeça, em meio à travessia de um chavascal, talvez as luzes que piscam ali longe sejam uma aldeia ou a periferia da cidade, logo, penso, "pode estar ali, morar ali". Qual o seu nome, a sua idade? Ocorreu-me lembrar daqueles cartões-postais colorizados e expostos nas vitrines dos hotéis e do aeroporto de Manaus, especificamente a imagem da Cidade Flutuante, uma vista do alto cujos caminhos sinuosos remetiam a uma cobra grande. Foi então que me disseram que os moradores que habitavam a Cidade Flutuante foram transferidos para o bairro da Raiz. Pensei, "pronto, aí está um começo". Vamos começar nossa busca pela Raiz, no igarapé do 40. Através da União do Vegetal ${ }^{2}$ conseguimos nos aproximar dos moradores mais antigos, e nos foi apresentado um senhor com farta cabeleira e dignos bigodes brancos.

"Francisco Sátiro Pereira, seu criado, setenta primaveras completadas neste ano mesmo. Todo mundo por aqui só me conhece como Chico Bacurau”.

Ele continuou a balançar-se na rede enquanto escutava meus porquês. Lá pelas horas tantas, com uma voz grave e mansa me diz:

"Dessa missa, o senhor não sabe nem o terço". 
É dezembro. O tempo das chuvas, as mangueiras estão repletas de mangas, ainda verdes. Depois de três meses de cadeia, o jovem Chico Bacurau, no início dos anos de 1960 recebeu indulto natalino do também jovem governador do Estado. Chico Bacurau não havia cometido crime, assim por dizer, crime de verdade, não, apenas tinha surrupiado um pouco de dinheiro que encontrou numa caixa de sapatos, onde o português Felipe Geleiro guardava parte das suas economias. Tanto que anos depois, ao morrer solitário e sem o amor de ninguém, foi encontrada uma fortuna de dinheiro dentro do velho colchão onde dormia. Fortuna é modo dizer: a maior parte já havia sido consumida pelas traças, pela inflação e pelas mudanças da moeda nacional.

Chico Bacurau, como quase todo mundo em Manaus, veio de longe, por ali mesmo, desceu desde o rio Urariá, médio Amazonas, veio parar na capital e logo se apegou a uma dona, a Sidinéia, e com ela começou a fazer vida, quando construíram uma casa na Cidade Flutuante. Até então nunca havia calçado um par de sapatos. Mas naquele dia, quando atravessou os pesados portões da Penitenciária do Estado, caminhou a pé com sua mala de papelão, passou pela segunda ponte e de longe viu uma multidão reunida em frente ao Palácio Rio Negro e ele se lembrou daquele jovem governador que distribuía brinquedos para as crianças pobres no Natal e lápis e cadernos na jornada escolar. E ele mesmo, agora, sentia-se grato. Pensou em ficar por ali, misturar-se à multidão e agradecer-lhe pessoalmente. Infelizmente, naquele momento a sua idéia era única e uma só, chegar à Cidade Flutuante, entrar em casa e jogar a Sidinéia na rede e mostrarlhe com quantos paus se faz uma canoa. Ah, isso ela ia gostar. "Dá-lhe pau de miratinga!”.

Enquanto a turista de cabelos louros e olhos azuis gira a vitrine dos postais, pára no postal da Cidade Flutuante e espia com atenção. Em outro lugar, um menino segurando as mãos do avô - Mestre Joaquim, arquiteto sem diplomas, construtor de tantas casas e até da Igreja Matriz da sua cidade no interior. Ele é um cearense de Sobral que gostava de sair caminhando pela cidade com o neto, falando coisas que parecia não querer dizer exatamente para o neto. Sim, o que significa aquelas casinhas espalhadas e fugidias às margens dos rios, lagos e igarapés? "É apenas um cenário indicando uma maneira poética do solitário homem ribeirinho viver, enfrentando carapanãs, malárias e outras feras?".

Esta é a mesma paisagem que nos desafia a sair das águas, romper a frágil ponte do porto que nos liga ao resto do mundo, espiar o próprio umbigo e descobrir que a vida se une a tudo e a todos num só sentimento, pedaços, fragmentos das histórias que nos contam. Prisioneiros num fotograma, entre as duas margens da memória - negativo e positivo, p\&b e a cores. Neste caso é conveniente o imaginário dos filmes $\mathrm{Meu} \mathrm{tio} \mathrm{o}^{3}$ e $\mathrm{O}$ homem do rio $\mathrm{h}^{4}$, o primeiro é uma sátira sobre o comportamento e o cotidiano de uma família burguesa, utilizando a visão da nova tendência, os bairros residenciais com sua arquitetura moderna, asséptica, artificializada e fria como uma lápide de mármore em contraste com a 
vida da Paris antiga, tradicional, onde os vizinhos convivem num relacionamento amistoso. O outro tem uma particularidade, parte das filmagens foi realizada na Cidade Flutuante, em Manaus. Tornou-se um dos maiores sucessos cinematográficos da época e foi indicado para o Oscar de melhor roteiro. Com uma narrativa que exalta o cinismo, a dinâmica das histórias em quadrinhos e o nonsense, aliás, como tudo mais irá permear os tempos da guerra fria - os filmes de 007.

Não havia estranhamento algum na escolha de locações, mesmo que elas fossem a paisagem da miséria que, aos olhos de hoje, gera uma certa ameaça física, naquela época se ajustava perfeitamente ao romantismo do "terceiro mundo" e do "precário". Tanto que, no Rio de Janeiro, onde as favelas eram vistas como o berço do samba, chegou-se a cogitar colorir os barracos com cores diferentes para amenizar o "incômodo" da miséria social urbana. O cinismo dessa proposta aconteceu concomitante à escandalosa "operação mata-mendigos" - retirá-los da zona sul da cidade maravilhosa e afogá-los nos rios Guandu e da Guarda. Por incrível que pareça, é fato, e o plano foi colocado em prática. Por outro lado, aparentemente, os cariocas, assim como os amazonenses, pareciam não se envergonhar da paisagem "precária", tanto que elas eram vendidas como cartõespostais.

Chico Bacurau nunca tinha ido ao cinema, já tinha ouvido falar dos filmes de "bang-bang" e $A$ vida e paixão de Jesus Cristo ${ }^{5}$. Nunca havia passado pela sua cabeça trabalhar como artista de cinema, e olha que ele se considerava "pau-p'ratoda obra".

Numa manhã chuvosa, os produtores franceses do filme $O$ homem do rio desembarcaram em Manaus para fazer a pré-produção e escolher as locações. Não podiam ter encontrado melhor lugar para se hospedarem, senão o Hotel Amazonas, o único da região com ar condicionado. Ele ficava situado estrategicamente entre o Porto Flutuante, o Mercado Municipal e o lugar inusitado que eles não imaginavam existir por ali, a Cidade Flutuante. Aquela paisagem, numa arquitetura dançante, impressionou-os. Chico Bacurau, como os gringos, também pouco conhecia de Manaus, tudo que estivesse depois desse triângulo urbano e arquitetônico, nem mesmo o Teatro Amazonas nunca havia visto assim cara a cara, ele o conhecia de longe, a cúpula refletindo a luz do sol por entre os edifícios da cidade. Mas naquele dia, enquanto se dirigia para a Cidade Flutuante, ele não conseguia em esquecer Sidinéia, era uma surpresa, no alto da barranca ele tenta localizar a sua casa, misturada num emaranhado de caminhos de tábuas e toras de madeira, ele desce como pode, equilibrando-se, cruza com um homem carregando nas costas um botijão de gás, eles se entreolham. Chico Bacurau segue em frente, o outro homem resolve voltar, equilibra-se para não cair ao ultrapassar perigosamente Chico Bacurau. Eles se reconhecem: era o soldado Viriato, que na ausência de Chico Bacurau ficou mais Sidinéia enrabichados, naquela troca de favores, ora uma enfiada de jaraqui, ora uns litros de farinha do arini ou um botijão de gás. Eis que a verdade os coloca frente a frente, Sidinéia surge por 
entre a viela, o soldado Viriato pega-a pelos braços, antes deixa no chão o botijão de gás, ele está vazio. Um forte cheiro de água suja, misturada ao pitiú dos peixes exala por ali. Chico Bacurau logo compreende o que aconteceu e o porquê de Sidinéia não fazer muito caso em ir até a Penitenciária recebê-lo na saída. Aquilo que parecia resultar em paixão, tesão e sexo transformou-se em raiva, ódio. A força da fúria fez Chico Bacurau jogar o botijão de gás sobre a cabeça de Sidinéia, ela cai e uma poça de sangue mistura-se às águas do rio Negro, também manchado de óleo, gordura e bosta. Ao longe, no meio da algazarra, dos gritos populares "não deixa o assassino fugir", os produtores franceses viram-se no meio de uma grande cena, ao presenciarem o Chico Bacurau fugir através de um buraco que, evidentemente, só podia levá-lo às águas do rio. Este, nadando por debaixo da Cidade Flutuante, consegue escapar de bubuia. O intérprete traduziu aos gringos o que havia dito o delegado Almir Omar: "Esse meliante escapou por debaixo desse labirinto, mas não vai ser por muito tempo. Peixe que é peixe sempre é obrigado a vir buscar oxigênio fora d'água".

O delegado, ao notar que os gringos estavam interessados na sua opinião, aproveitou para exibir sua sabedoria regional.

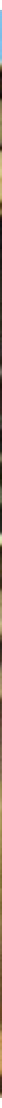

Detalhe da Cidade Flutuante no início dos anos de 1960. Cartão Postal de Manaus. 


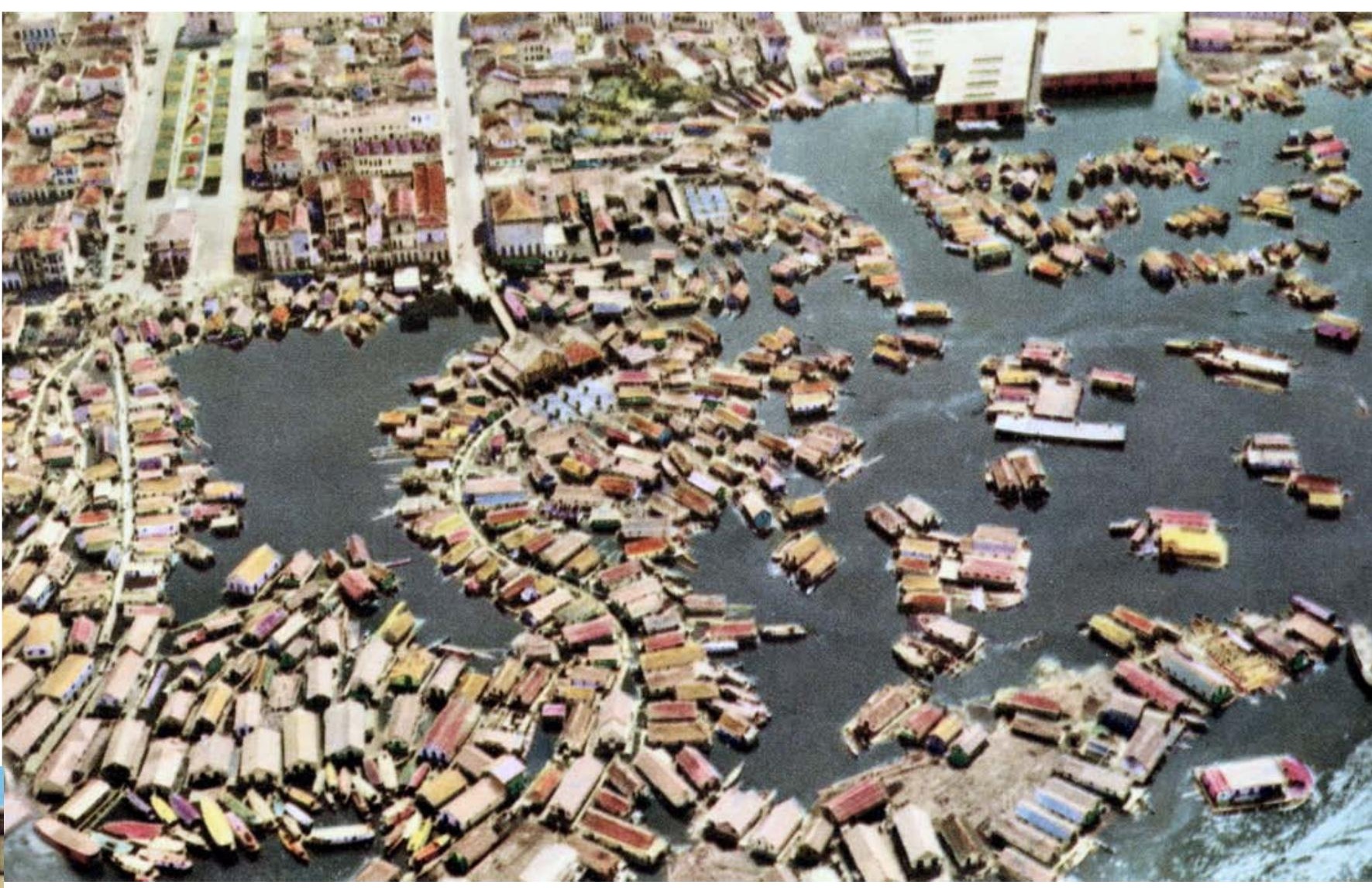

Vista aérea da Cidade Flutuante no início dos anos de 1960. Cartão Postal de Manaus.

"A vida do homem nessa região é uma realidade anfíbia, daí esse pessoal não se intimidar com a fúria do sobe e desce das águas. Eles vão construindo suas casas palafitas, e não só elas, mas toda e qualquer atividade: lojas, postos de gasolina, quitandas, botecos que, estruturados sobre toras e ancorados em pontos que facilitem o comércio, funcionam em tempo de cheia ou vazante. Aqui é a Manaus que nunca dorme".

Essa última frase soou como canto de sereia aos ouvidos dos produtores. Haviam achado a sua locação. No filme O homem do rio, o ator francês Jean Paul Belmondo movimenta-se sem inibição de qualquer natureza. Em questão de segundos ele sai de Paris, entra no avião, desembarca no Rio de Janeiro, pula sobre a floresta amazônica, desafia seus desafetos entre as vielas da Cidade Flutuante em Manaus, equilibra-se nos andaimes dos monumentais prédios em construção de Brasília. Nada que não estivesse dentro da tendência cinematográfica do pós-guerra, narrativa fragmentada, com enquadramentos e montagens desconcertantes. A partir dos anos de 1960, o ciclo histórico da invenção do cinema parece completar-se e ele se impõe como uma malha de rios, num curso de vários matizes e tendências, reconstruindo-se sob auto-referências. $\mathrm{O}$ filme Acossado $0^{6}$, Je Jean-Luc Godard, também estrelado por Jean-Paul Belmondo, é um exemplo desses filmes que iniciam uma nova era para a narrativa cinemato- 
gráfica, onde as palavras são substituídas pelas imagens, o que de resto é a linguagem do século XX.

A floresta Amazônica ainda não era tema sob o conceito da "ecologia", "meio ambiente" ou "a riqueza do seu banco genético"; mesmo que tudo isso já existisse como valor, era um orgulho viver numa floresta cobiçada internacionalmente, tal como dizia o título do livro mais vendido na época $A$ Amazônia e a cobiça internacionat. Em outras palavras, na Amazônia se escondia o futuro: a maior reserva de água doce do planeta, onde vivem mais de três mil espécies de peixes, o equivalente a $23 \%$ do mundo. Cabem na Amazônia brasileira nada menos que $98 \%$ da Europa, o mesmo continente de onde vinham aqueles gringos, mas Chico Bacurau nem mesmo havia escutado falar dessa "tal Paris", e acrescentou: "p'ra mim era nome de mulher-dama".

Mas quem se importava com essas histórias e a das famílias que tinham ficado ricas com a matança de animais, vendendo a carne, a gordura, a pele ou o couro e exportando ilegalmente peixes ornamentais, borboletas, orquídeas ou pedras preciosas encontrados na "Manoa del Dorado"? Para constatar esse saque, bastava caminhar pelas ruas comerciais, onde ficavam os escritórios e os armazéns, nas ruas Teodoreto Souto, dos Barés, Marechal Deodoro, Marquês de Santa Cruz, na Ladeira dos Remédios ou pela avenida Eduardo Ribeiro, por todo lugar podiam-se ver pilhas e pilhas de couro de cobra, ariranha, jacaré, onça, jaguatirica e outros animais esperando o momento para serem embarcados e tomar rumo ao mercado consumidor, europeu ou norte-americano. Nada causava espanto ou indignação, nem mesmo a publicação da reportagem no jornal da cidade, "Negase Ficar no Solo o Petróleo de Nova Olinda", diante do óbvio que aflorava na superfície da terra naquele município as margens do rio Madeira, "aqui tem tanto óleo que já está saindo sozinho, sem ajuda de ninguém”, diziam seus habitantes.

Essa afirmativa não chegava a sensibilizar qualquer interesse para uma investigação ou mesmo reivindicação de propriedade por parte da população ou das autoridades; eles diziam, "é petróleo, mas não é comerciável". E logo ali, na fronteira norte, na Venezuela, o petróleo jorrado fazia fortunas, mas como dizia o sarcástico Mestre Joaquim: "Veja só, seu pai-d'égua, esse petróleo que tanto jorra na Venezuela quando ele chega nas fronteiras políticas do nosso Brasil, empaca feito um jumento e dá uma meia-volta e nos deixa comendo a raiz da macaxeira. Estranho, muito estranho".

Hoje, isso não é mais novidade alguma, os estudos da Petrobras indicam que a reserva de gás natural na bacia do Solimões é estimada em 130 bilhões de $\mathrm{m}^{3}$, o suficiente para abastecer a região por pelo menos trinta anos, e as novas descobertas em outras áreas, inclusive a de Nova Olinda do Norte, podem ampliar esse potencial para mais de um século.

Tanto a denúncia do solitário repórter como o sarcástico comentário do Mestre Joaquim estavam certos, a natureza não poderia empacar feito um jumento, somente para respeitar fronteiras políticas. 
Naqueles anos de 1960, Manaus era um nada, mas um nada que era um tudo. Pelo menos para as quase trezentas mil pessoas que a habitavam e sentiam orgulho do passado recente, o ciclo da borracha, que fazia sentido para massagear a importância dos amazonenses no mundo ou para o resto da humanidade e assim foi para a geração nascida até 1968. Apesar da sua baixa densidade populacional, a Amazônia, com uma população que ultrapassa vinte milhões de habitantes concentrados nas principais cidades, abriga também a maioria da população indígena brasileira, que fala 140 idiomas. E como tudo isso não bastasse, há, nessa floresta, cinqüenta grupos indígenas em plena era neolítica, alheia à realidade que se avizinha e os ameaça.

$\mathrm{Na}$ vida de Chico Bacurau, desde a Cidade Flutuante até a sua casa no bairro da Raiz, muita água rolou por debaixo daquelas três pontes. Ele fez de tudo, acabou por ir trabalhar numa serralheria, primeiro fazendo cadeiras de balanço de ferro e fios de plásticos, as famosas "cadeiras de macarrão", depois grades e portões de ferro. As pessoas pareciam querer viver enjauladas, algo que remetia à sua temporada no inferno da Penitenciária do Estado. Mas foi nessa atividade que conseguia juntar um dinheirinho para casar e criar os filhos. Agora ele se sentia um pássaro aposentado e sem poder realizar grandes vôos.

"Olha essa Manaus, cresceu muito, agora nem sei onde ela começa e onde acaba. A cidade deu um nó na selva feito uma sucuri".

No tempo do Chico Bacurau e da Cidade Flutuante, havia os programas de rádios, mas não televisão. A saída e a chegada na cidade tinha que ser através dos aviões ou pelos navios de carreira.

A Manaus continental era uma ilha, mas nem tanto. As rádios anunciavam notícias, com fundo musical, no almoço. Na Difusora, às $12 \mathrm{~h} 00$ - "A crônica do dia" com O vôo do besouro, de Rimsky-Korsakov, e às $19 \mathrm{~h} 00$ - "A voz do Brasil" sob os acordes da protofonia de Oguarani, de Carlos Gomes. Além disso, havia os boleros de Augustin Lara (Granada, Mujer, Noche de Ronda, Solamente uma Vez, Farolito), Roberto Cantoral (El veloj, La Barca), Consuelo Velásquez (Besame Mucho), Gonzalo Curiel (Vereda Tropical), todos eles compositores de músicas que ficaram famosas na voz de Bienvenido Granda, Pedro Vargas, Lucho Gatica, Elvira Rios, Nelson Gonçalves, Anísio Silva, Altemar Dutra, Dolores Duran, Maísa, Ângela Maria, Miltinho, Dalva de Oliveira, Orlando Dias, sem esquecer o cantor Salim Gonçalves, o seresteiro do Amazonas. Esses boleros e os sambas-canção chegavam tanto através das ondas curtas do rádio como pelas interpretações que se fazia na cozinha ou no chuveiro. Enquanto o bolero se tornava cada vez mais cosmopolita na voz do cantor negro norte-americano Nat King Cole (Quizas, quizas, quizas) ou da espanhola Marisa Montiel (Noche de Ronda), Harry Belafonte com a música jamaicana Matilda, fazia do Calipso uma mania mundial. Tudo isso, com certeza, fazia sintonia com o gosto popular. O cantor Jackson do Pandeiro, com o sucesso Chiclete com banana, era o sinal que seria bem-vindo toda e qualquer mistura artística e cultural. 


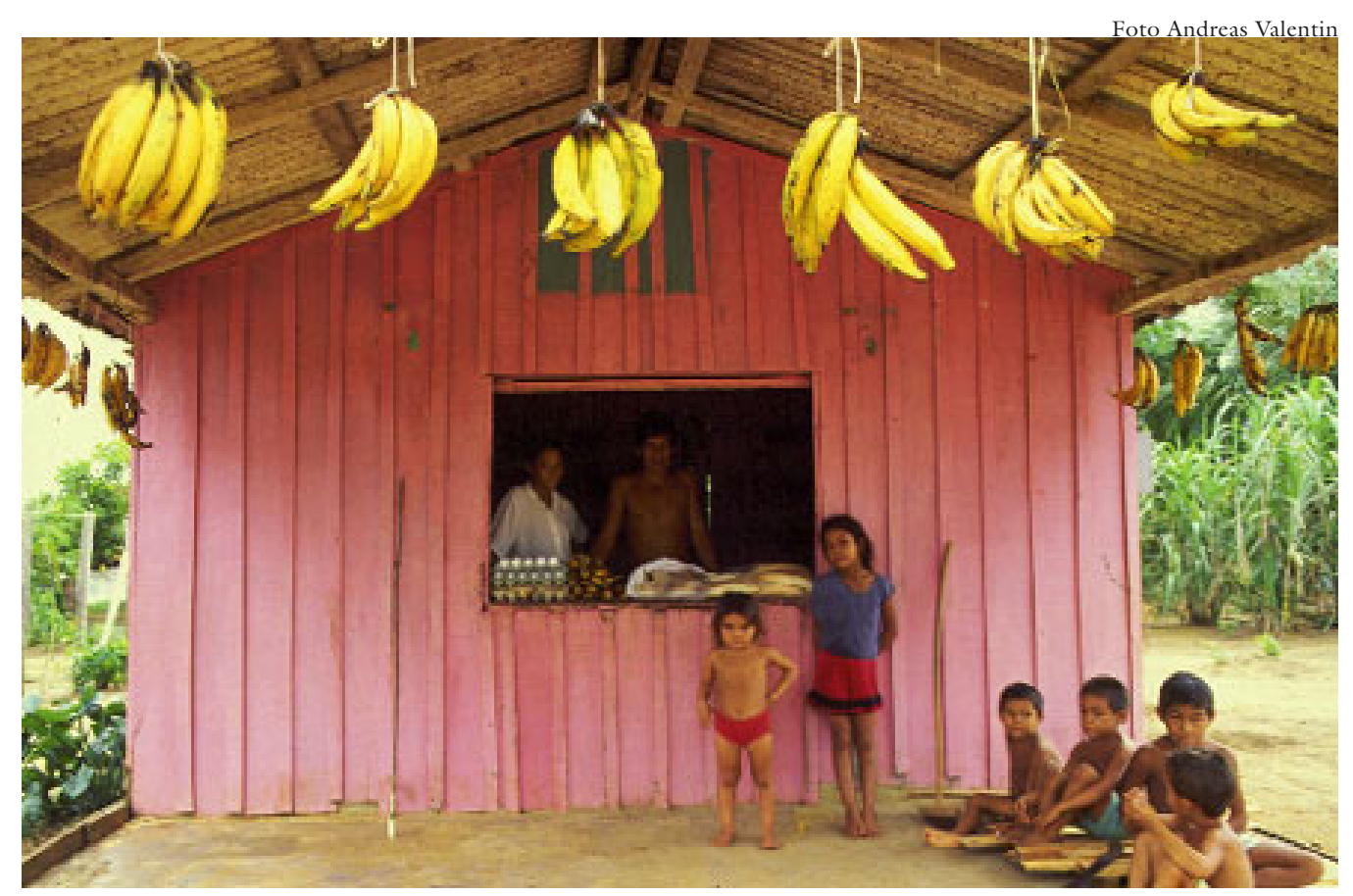

Crianças ribeirinhas em frente à mercearia de produtos regionais.

As famílias da classe média só rompiam os limites do seu gueto, o centro da cidade, quando necessitavam sair de Manaus por via aérea, em direção ao aeroporto de Ponta Pelada. $\mathrm{O}$ acesso principal era feito ao atravessar três pontes de ferro, a primeira, a segunda e a terceira, que é mais bela e monumental. A primeira ponte significava sair de um mundo já conhecido, atravessar o igarapé de Manaus para vislumbrar o Palácio Rio Negro - a sede do governo, antiga residência de um rico seringalista alemão, que mantinha um zoológico particular. Dizem que lá aconteciam festas do arromba, com eunucos, hipnotizadores, odaliscas, uma verdadeira Sodoma e Gomorra. Depois, veio a crise da borracha e ele teve que vender tudo, até os sapatos e as gravatas. Tudo isso fazia parte das mil e uma noites das lendas manauaras.

Na segunda ponte, um receio misturado ao desafio de encarar aquele mórbido prédio, parecia uma fortaleza, a Penitenciária do Estado, "aí estão presos os ladrões e assassinos". Na terceira ponte, a mais incrível, tanto por causa do arrojo da sua edificação como pelas histórias recorrentes, contada pelos adultos. "Sabu saltou daqui".

Essa frase soava desesperadoramente espetacular. Tantas foram as vezes que se ouviu "Sabu" que ele se tornou um conhecido, alguém que morava por ali perto, numa daquelas casas flutuantes. A frase "Sabu saltou daqui", no entanto, é o tipo da história que se adquire por outros, ela repercute e vai se apossar da memória alheia, alguém que não a vivenciou, mas se tornou seu provedor.

Sabu existia de fato, mas infelizmente não morava por ali, ele era um astro do cinema internacional. Sabu era, na verdade, o ator indiano-mirim dos filmes de aventuras exóticas do tipo Ladrão de Bagdá, e visitou Manaus acompanhado 
da atriz Bibi Ferreira por ocasião da divulgação do filme $O$ fim do rio ${ }^{8}$, cujo cartaz trazia a frase "Onde a lei da natureza começa - a civilização pára". Algumas cenas desse filme foram filmadas em Belém e Manaus. Contam que Sabu, ao ver a ponte, vindo do aeroporto de Ponta Pelada, fez questão de saltar lá do alto mergulhando espetacularmente nas águas do Igarapé. Até hoje ninguém soube responder satisfatoriamente a essa polêmica: afinal, o Sabu saltou da segunda ou da terceira ponte?

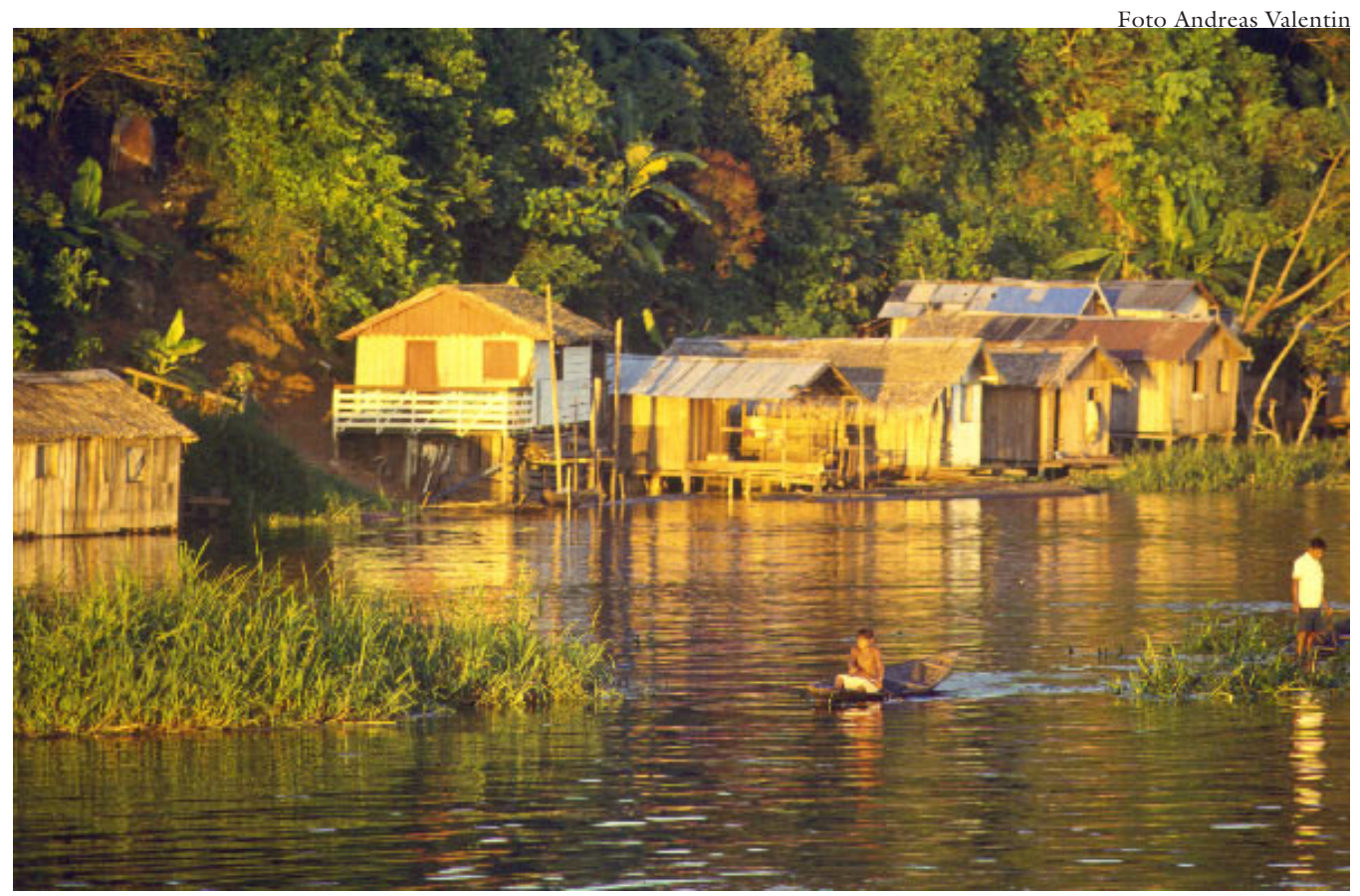

Construções flutuantes típicas da região amazônica.

Chico Bacurau manda baixar o volume da televisão, diz gostar desses programas onde o povo pode falar, dizer o que sente, pedir aquilo que não thes deram. "Esse povo precisa muito de ajuda, sabe". Ainda hoje, pode-se dizer que para a grande maioria dos que habitam a selva amazônica, a televisão, paradoxalmente, é a única janela ou ponte para o mundo exterior. É muito comum no meio da paisagem, ou no alto, identificar a presença paradoxal da antena parabólica, no meio daquele aparente vazio. Ali dentro daquela casa ribeirinha, a TV ligada no mais alto volume noticia banalidades: guerra, violência, fome, miséria, desemprego, corrupção, como se fosse um incurável vício, obcecado na idéia da destruição, no esgotamento de recursos terrestres. A reação de Chico Bacurau é pura perplexidade: "Mas como se mata por aí, seu coiso, se morre é de porção, parece que a vida lá fora não vale nada, será que isso é o progresso?” Ele está certo, essa idéia do progresso é recente, surgiu entre os séculos XVII e XVIII, quase no mesmo tempo da fundação da cidade de Manaus, que custou, segundo se calcula, a morte de quase trezentos mil índios. Para esses povos não existia a fé no progresso, e a vida fazia parte do ciclo da natureza. Mesmo assim, isso não os 
redime da humanidade, porque não foram menos violentos ou menos cruéis. "Já estou mais pra lá do que pra cá, portanto, o que importa é estar nesse lado e aqui permanecer, aguardando o momento da grande travessia para o lado de lá", comenta Chico Bacurau. "Olha, mais vou te dizer, aquela dona não morreu não, apenas levou um corte aqui, em cima das sobrancelhas, caiu desmaiada e depois levou uns pontinhos e caminhou pelas águas. Mas ela não era nenhuma santa". Ele se referia a Sidinéia: desfazendo os nós da sua história, Chico Bacurau conta que ficou por ali perambulando feito um condenado. Ele fez jus ao seu apelido, Bacurau, a ave com hábitos noturnos e que tem a artimanha de ficar imóvel de tal jeito que até parece tomar a forma da árvore onde estiver pousada. Do lado dos homens da lei, o delegado Almir Omar fazia vistas grossas. Os gringos da filmagem acabaram contratando-o numa coincidente fusão de destinos. "O senhor sabe, eu conhecia aquilo tudo, cada tora de madeira que sustentava a Cidade Flutuante. Foi uma época muita pai-d'égua, coisa de rapaziada".

$\mathrm{Na}$ Amazônia falava-se da borracha como se ela própria fosse a bóia salvavidas que havíamos perdido em algum naufrágio. A cidade que Chico Bacurau não conheceu, além da Cidade Flutuante, tinha sido próspera. Em 1912, com a queda do preço da borracha, grande parte dos seus habitantes deixou quase tudo para trás, tendo as casas e os palacetes abandonados pela cidade se tornado substantivo, "as casas-velhas". Também não chegava a ser uma cidade-fantasma, a vida continuava numa lassidão sem fim e nessa atmosfera da "terra que já-teve", as pontes, as ruas, as avenidas, as praças e os monumentos pareciam um cenário que havia sido abandonado depois de utilizado numa filmagem.

As "casas-velhas", utilizadas pelos meninos como esconderijos, eram habitadas por atrevidas e gigantescas árvores que cresciam no meio da sala de jantar, rompendo o chão de mármore, os ladrilhos hidráulicos venezianos, os afrescos das paredes emboloradas, recriando uma outra obra pictórica, cujos musgos num degradé de verdes fosse de autoria de algum artista moderno, ou com seus galhos e trepadeiras exibindo-se pelas portas e janelas afora, enrolando-se por entre os ferros dos gradis recriando uma art nowveau da natureza.

Parecia que a selva havia retomado o lugar donde havia sido expulsa, mas para os meninos era apenas um refúgio de desafio ao proibido e ao medo, no meio dos formigueiros, urtigas, cobras, lagartos, enviras, tajás e bostas recentes e petrificadas. Perambulavam pela cidade alguns personagens que serviam como referência ao desastre do "fausto da borracha", eles davam um ar dramático por que passou (ou passava) a região amazônica, era uma espécie de atores que haviam atuado como protagonistas neste cenário e agora não passavam de meros figurantes, espécie de antigos astros e estrelas em decadência, como por exemplo, "o Astronauta" que vagueava pela cidade, carregando pastas e cadernos ensebados e uma caixa de lápis a cores, do tipo utilizado pelos marceneiros; o seu apelido vinha da relação imediata dos seus sapatos manufaturados e improvisados por ele, eram camadas de papelão e couro, para os meninos ele era imenso, causava 
medo e incitava curiosidade. Ao caminhar, seu corpo equilibrava-se no alto daqueles sapatões como o andar desengonçado das crianças e dos astronautas. Nunca era visto conversando com alguém e vivia absolutamente sozinho. Os adultos comentavam que havia sido muito abonado, riquíssimo, filho de um verdadeiro "barão da borracha", tinha estudado na Europa e que havia queimado toda a herança deixada pelos pais, tanto a mãe como pai haviam se suicidado ao saberem da queda do preço da borracha. O "Astronauta" desafiava a compreensão de quantos tentavam compreender sobre a efemeridade da riqueza e do mundo. Todas as vezes que se podia avistá-lo parecia que todo o resto deixava de existir, tudo ficava congelado e somente o "Astronauta" se movimentava, feito um robô. Ele, sem dúvida dava-nos a dimensão efêmera do poder.

Mestre Joaquim, quando se encontrava em Manaus, gostava de apreciar esses personagens, acompanhava-os com a curiosidade de um espião, queria saber onde dormiam, o que comiam (se comiam) e o que falavam, aproximava-se chegando o mais perto que conseguia e ficava com a bituca do seu cigarro escutando as palavras balbuciadas. Um dia, segundo ele, escutou o "Astronauta" dizer: " $\mathrm{O}$ homem é um ser circunstancial... circunstancial. O X é igual mais $\mathrm{Y}$, portanto somos = XY".

Mestre Joaquim costumava referir-se a essa frase para defender a sua tese sobre "o mínimo do mínimo" que o homem necessita para viver na Amazônia: "Aqui o homem precisa de quase nada pra viver, um calção e mais um pouco. É muito barato, será por isso que o governo faz pouco caso?".

$\mathrm{Na}$ paisagem urbana cruzavam-se sem se encontrar outros personagens que haviam vivido a farra da borracha e que haviam torrado as suas últimas libras esterlinas. Como, por exemplo, um dândi, que parecia estar deslocado da sua época, vestido com suas finas roupas surradas como se estivesse saindo ou indo para uma festa a rigor, isso a qualquer hora do dia ou da noite, fizesse calor, mormaço ou chovesse. Seus cabelos nunca se encontravam em desalinho, sempre penteado com os cabelos lustrados, um bigode que mais parecia Max Linder, aquele personagem do cinema francês.

Diziam que ele havia matado o pai, junto com outro irmão e jogado o corpo no rio Purus, quando aí navegavam, vindo das terras onde ficava seu território feudal, quer dizer seringal.

Essas e outras pessoas costumavam ser personagens bastante presentes em nossa infância. Sobre eles aprendemos a escutar seus relatos com interesse e sedução.

Enquanto escuto a narrativa do Chico Bacurau, imagino os contrários que nos diferenciam e nos unem. Ele, o Chico Bacurau, habitava a cidade que desconhecíamos ou fingíamos não existir como realidade, aquela cujo fedor não cabia no cartão-postal. Os meninos daquela outra cidade aguardavam meio adormecidos para serem convidados para acompanhar o Pai ao Mercado Público, apreciar o amanhecer sob o frescor dos ventos. Sempre se encontrava alguma pessoa, 
caminhando silente e encolhida em direção aos seus afazeres, era sempre a mesma, mas nunca as veria depois daquela hora. No Mercado, no meio daquele templo art nouveau, fascinava-me o agito e o alarido da bagunça organizada dos vendedores, peixeiros, açougueiros, verdureiros e fruteiros, mas também sentir o cheiro que exalava dos peixes, das frutas e do tucupi no tanque, jambu, pimenta de cheiro e malagueta, urucum, as farinhas de surui, d'água e do arini, as especiarias de banho de cheiro para magia do encontro e desencontros no negócio chamado "amor". Tinha sempre a mesma perturbadora sensação das imagens que surgiam. Uma canoa afastando-se da casa à beira do rio. Via Chico Bacurau, personagem épico remando nas galés romanas e fazendo seus músculos trabalharem. Longe, a linha do horizonte demarcava as distâncias medidas sob a linha d'água. Chico Bacurau, depois de passar uma noite completa em pleno luar, com o arpão nas mãos, equilibrando-se na canoa, tentando acertar o pirarucu quando surgia à tona para respirar e o seu lombo escamado refletir a luz da lua. Chico Bacurau, atento a esse reflexo, lança seu arpão atingindo-o em cheio. $\mathrm{O}$ enorme peixe, com raiva e dor, tenta se desvencilhar e fugir para o fundo do lago. Chico Bacurau, em cima da canoa, faz-de-um-tudo para não cair n'água e perder a presa, havia chegado a hora, era ele ou o pirarucu.

$\mathrm{O}$ enorme peixe arrasta por alguns minutos a canoa como se ele estivesse esquiando, até que o pirarucu cansa, desiste e sob pauladas certeiras e doloridas entrega-se. Em seguida, já desfalecido, ele é jogado para dentro da canoa. Chico Bacurau, exausto, recupera o fôlego respirando fundo todo o ar de felicidade que o trabalho daquela noite lhe trouxe mais uma vez. O pirarucu renderia muitas semanas de mesa farta, sem falar a parte que iria salgar para guardar para os meses de muita chuva. Ainda remando, ele sai do lago e atinge o canal do rio que lhe leva ao igarapé, onde sua casa, mãe, irmãs e irmãos o aguardam.

Chico Bacurau salta da canoa, empurra-a para a terra firme, pega os apetrechos. Vejo-o carregar o remo numa das mãos e um imenso pirarucu nas costas. Ajudado pelos seus irmãos, segue subindo o declive da praia e sumindo por trás da sua casa no Urariá.

Minha sensação imagética é interrompida por Chico Bacurau: "Hei, seu coiso, parece que está perdido, acorda, ainda estamos no princípio da nossa prosa. Fecha essa boca senão acabas engolindo uns carapanã”. Realmente, encontravame maravilhado pela sensação espetacular daquele encontro, mesmo assim, sentia-me em pleno Mercado Municipal, imerso no burburinho dos peixeiros e acompanhava os sons e ruídos verberarem pelos quatro cantos, subindo para o alto, chocando-se nos vitrais por onde fachos de luzes penetravam acrescentando um toque mágico naquela madrugada quando as pessoas escolhiam com cuidado, primeiras com os olhos e depois pedindo para o vendedor exibir a peça do peixe ou do pernil que deveriam comprar. Mas tudo isso não queria dizer nada, não fosse o vozerio dos peixeiros, chamando a atenção dos fregueses, o rádio tocando alto e o cheiro forte dos peixes. Eles levantam o terçado que corta com toda 
a força o tambaqui em bandas, fragmentos das suas vísceras. Posso senti-los atingirem o meu rosto, reajo, afastando-me, e isso me faz observar por trás do peixeiro o gradil do Mercado Público, com os urubus pousados em cima das suas grossas setas de ferro. E antes que a minha a atenção ficasse dispersa, o baque surdo do terçado misturava-se com o barulho imaginário da água num banzeiro.

A imagem num plano próximo, quase cara a cara, surgia Chico Bacurau, balançando-se na rede, oferecendo um suco de cupuaçu, confundo-o com o Mestre Joaquim, com seu rosto coberto com uma rala barba branca, com olhos cor de mel, num cinismo que dava gosto, fazer seus comentários quando a cachaça batia zonza nos miolos ribombando pelas idéias, lembrando-o das responsabilidades familiares, os filhos, quase homens, as filhas prontas pra casar. E aí que ele se sentia lascado. "Se o mundo fosse bom, o dono morava aqui. E tem mais. Ninguém nascia chorando."

Mestre Joaquim fazia história, quando solicitado para um serviço, construir ou reformar residências, ele sugeria fazer um puxado, aumentar os quartos, a sala de jantar para atender as novas necessidades, aconselhava: "A dona fulana está esperando mais um herdeiro, pois não?”. "A sua filha está um botão em flor, merece um quarto só pra si" ou "O herdeiro está um rapagão, é melhor reservar uma gaiola pra esse periquito". Trajando-se sempre com sandálias, que na época chamavam de "arigó", e seu inseparável casaco de algodão, nos bolsos trazia lápis de cera que usava para desenhar os croquis, projetos, plantas baixas ou o desenho das portas, mesas e cadeiras, fosse onde fosse, numa folha de papel de embrulhar pão, no terreiro onde se iria construir ou mesmo numa tábua de madeira, tudo valia para fazer o desenho. Era o arquiteto sem diploma. Com esse jeito displicente e alegre ele angariava simpatia, tornando-se um personagem muito popular na cidade.

"Olha, vou lhe dizer, esse tipo de moradia amazonense, é muito interessante, ela de dia te refresca e de noite te aquece, nas noites de chuva então".

O Mestre Joaquim não estava sozinho, no final do século XIX, foi observando essas edificações flutuantes que os ingleses optaram por construir o Porto Flutuante de Manaus, utilizando sistemas de balsas de ferro em vez de toras de madeira. Essa estrutura existe e funciona até hoje. À primeira vista, seus habitantes parecem ilhados, mas sua relação com a água é tal que é possível ver até mesmo crianças bem pequenas se deslocarem com a maior desenvoltura pelas canoas que cruzam as águas. Antes, quando havia abundância de palhal, utilizava-se a palha de "buçu" para fazer paredes, divisórias e coberturas. A escolha primordial dessa palmeira deve-se a suas propriedades (ainda mal compreendidas) como antídoto contra insetos e fungos, além de sua durabilidade, que chega a até vinte anos. Hoje, muitas casas de palafitas passaram a ser cobertas com telhas de amianto.

Chico Bacurau ficou encantado com a possibilidade em se tornar ator. O seu amigo Pedro Louro havia tentado, sem sucesso, participar da produção ítalo- 
francesa Os bandeirantes ${ }^{9}$, e agora uma outra equipe de cinema francês se encontrava em Manaus e divulgou pelo rádio e jornais que estaria precisando de figuração para realizar algumas cenas na Cidade Flutuante. Foi aí que Chico Bacurau e toda a turma da Cidade Flutuante vislumbraram a grande oportunidade de exibir talento e quem sabe fugir com o circo. O que Chico Bacurau não sabia era como funcionava o ritual de um set de cinema, aquilo que parecia simples e rápido revelou-se complicado, a filmagem varou a noite, a madrugada, até que o dia surgiu. Chico Bacurau acabou participando da figuração no salão de baile, típica cena para mostrar o exotismo da região: pancadaria e bagunça generalizada, como nos filmes das chanchadas com Oscarito e Grande Otelo.

O curioso de todo esse episódio foi o ator francês Jean-Paul Belmondo, ele que já havia ganhado a fama de astro do cinema internacional, com o perfil do marginal moderno, seu padrão de beleza contrariava os bonitinhos rebeldes sem causa de Hollywood, mas ali ninguém sabia verdadeiramente a sua importância como astro, e ele, sem perder o pedestal, revelou-se o anti-herói da rebeldia em plena selva amazônica, enquanto fumava cigarros em profusões de uma chaminé, tomava caipirinhas de limão e em seguida jogava os copos no meio da rua, gritando: guesia!)

"Je suis le vilain petit canard de la bourgeoisie!" (Sou um palhaço da bur-

Mestre Joaquim, que naqueles dias passava uma temporada em Manaus, resolveu interpretar o causo:

"Ah, se fosse comigo, ia logo gastando todo o meu francês".

"Como assim, Mestre Joaquim, o senhor fala francês?"

"Oxente, não sabias, pois agora fique sabendo. Eu sou versado no idioma napoleônico. Certa feita apareceu um deles lá em Maués, na barraca do compadre Bizantino, ele ficou enrolado, fazendo beicinho e foi aí... Que aconteceu o acontecido."

"Bonjour, monsieur".

"Não é beiju, é côco".

"Comment s'appelle?".

"Não se come com a pele não, quebra-se".

"Comment?"

"Com a mão nada, seu burro, com terçado!".

"Se não quer comprar pra que pergunta, seu gringo?".

Quando O homem do rio estreou em Manaus, o orgulhoso Chico Bacurau estava junto com seu amigo Pedro Louro procurando se ver nas telas do Cine Guarany, mas finalmente, a surgir o famoso The End, eles não haviam conseguido. Ah, sim, ele desistiu da carreira de ator. É, mas o cinema não sabe o que perdeu. Inclusive porque a sua história é um filme. O filme $O$ homem do rio não só registrou a juventude do Chico Bacurau escondido em algum dos seus 
fotogramas - quem sabe depois de uma pesquisa cirúrgica se possa vê-lo - mas também a Cidade Flutuante, com suas ruas sinuosas, boiando no rio. O seu comércio funcionando 24 horas e movimentando uma economia paralela, um reduto da boemia, rufiões, prostitutas, contrabandistas, ladrões, poetas, escritores e turistas em busca do eldorado ou simplesmente comer um jaraqui frito com baião-de-dois. Na Amazônia, esse tipo de edificações flutuantes, a falta de conforto e de saneamento básico é compensada pela natureza generosa - estima-se que duzentas mil toneladas de peixes por ano são geradas na malha aquática amazônica. Cada pessoa consome mais de quarenta quilos de peixe por ano. Um valor bastante alto se compararmos ao consumo de peixes de outras regiões do Brasil.

Mas a Cidade Flutuante não agradava ao olhar da elite conservadora, causava vergonha e desconfiança. Numa época em que essas mesmas pessoas não davam bola para a paisagem à beira rio, eram os pobres que a ocupavam com suas casas de arquitetura ribeirinha. A elite construía suas residências no sentido norte, em direção ao fundo da selva. Ao contrário dos dias de hoje, quando o movimento é inverso, os pobres são expulsos para dar lugar aos condomínios fechados a margem do rio.

1964. Apareceram na Cidade Flutuante algumas senhoras dizendo que estavam fazendo uma pesquisa para melhorar a vida dos moradores. "Essa favela de palafitas perdeu o controle, está crescendo despudoradamente. Agora, vocês serão transferidos para a terra firme e vão morar num verdadeiro bairro residencial".

Foi o sinal para o início da longa temporada da Ditadura Militar. Não demorou a chegar às balsas, e quem pôde salvar alguma madeira, zinco, gamelas, cuias, palhas, recortes de revistas e fotos para reutilizar em suas novas casas o fez, mas quem não conseguiu acabou por contemplar a sua casa amarrada e arrastada por grossas correntes de ferro. O rio encarregou-se de engolir e esconder e fazer de conta que nada viu, somente algumas toras de madeiras imputrescíveis, que serviam como bases das casas - piranheira, piquiá, paracauuba ficaram de bubuia sob o comando e o destino da correnteza do rio Negro. E essa também era a certeza que $O$ homem do rio já havia ampliado a linha d'água no horizonte de Chico Bacurau. Pode-se afirmar que a sua vida foi o antes e o depois deste filme. Abrindo uma manuseada bíblia sagrada ele mostra um maço amarrotado dos cigarros da marca Gitanes: "É dos gringos", diz.

Quando menino íamos passear no Porto Flutuante de Manaus, o Roadway "o rodo", buscar ou levar algum parente ou mesmo visitar um grande navio estrangeiro; aproveitávamos então para ficar debruçados espiando aquele mundão das águas negras e apreciar os botos boiarem feito mistério:

"Essas águas, para onde vão quando o rio Negro faz a vazante? Seria como a vida, nascemos, crescemos e morremos, mas quanta besteira. Vive-se só pra isso, morrer?" 


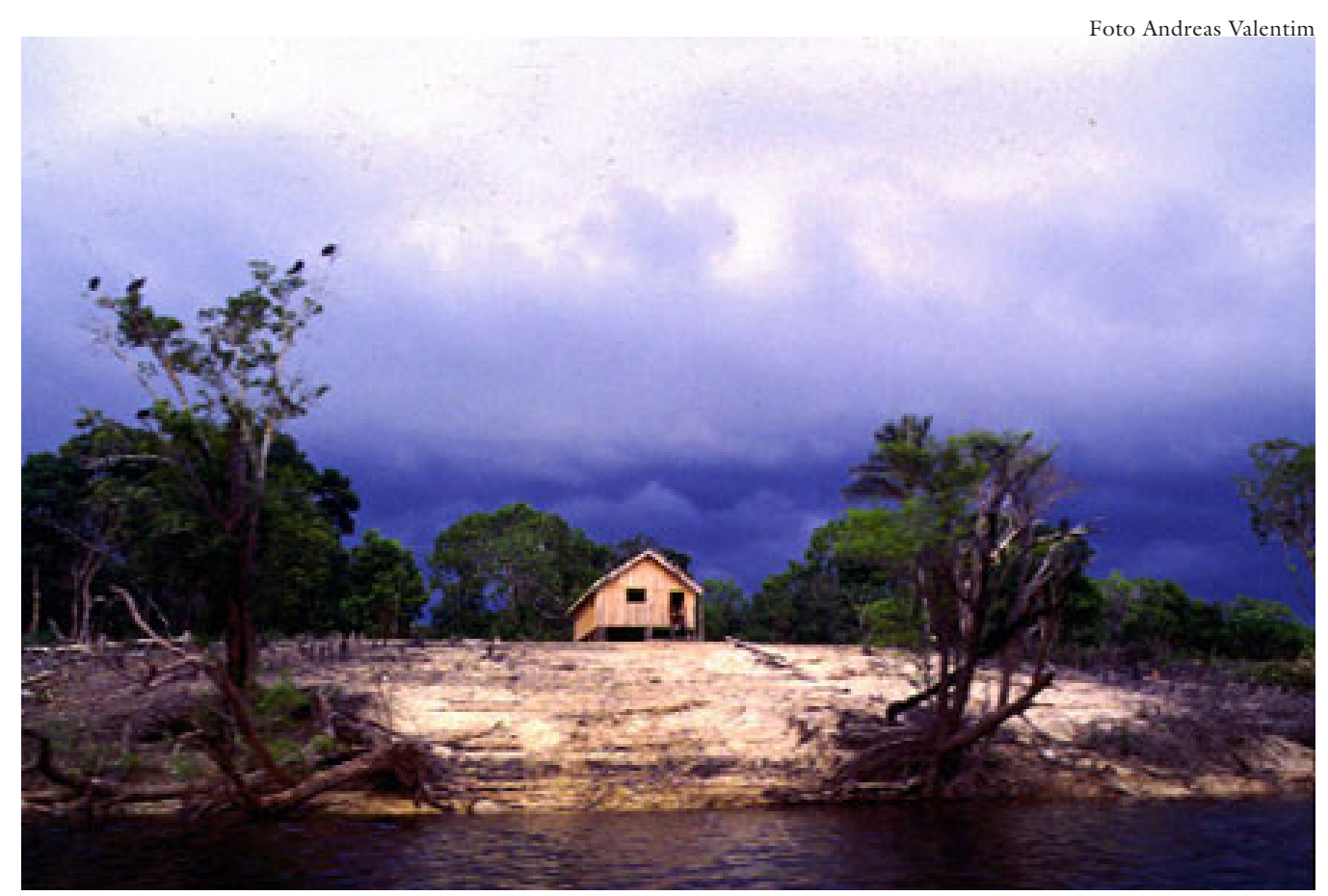

Casa ribeirinha no alto à margem do rio Amazonas.

Sempre éramos interrompidos por alguém:

"Cuidado curumim, não fica espiando desse jeito o rio senão tu acabas encantado por ele. O rio é traiçoeiro".

Logo após o golpe de 1964, Marechal Castelo Branco, então presidentemilitar, encomendou ao seu Ministro de Planejamento, Roberto Campos, uma solução econômica para o vazio administrativo do Rio de Janeiro, ex-capital federal: Zofran - Zona Franca da Guanabara. Essa proposta foi rejeitada pela oligarquia política carioca, eles não queriam a "cidade maravilhosa" transformada numa Hong Kong. O ministro Roberto Campos levou então essa questão ao Marechal Castelo Branco, e este, por ter vivido na região amazônica, viu nesse episódio uma oportunidade para responder a "ocupação do vazio", sugerindo que o Porto Livre fosse implantado na Amazônia, em Manaus precisamente. Isto foi feito a partir de $1967^{10}$. De repente, a cidade de Manaus foi invadida por forasteiros de várias línguas, religiões e nacionalidades. Logo as placas começaram a poluir visualmente todo e qualquer espaço do centro da cidade, nomes estrangeiros, vozerio dos ambulantes que se atropelavam na possibilidade que algum dos transeuntes pudesse comprar "de-um-tudo" que tinham pra vender. A partir daí torna-se impossível tentar reconhecer determinados cheiros, como os do sernambi, da piaçava, da essência do pau-rosa, da andiroba, da copaíba ou mesmo de peixe frito ou assado. O cheiro do rio? E o rio ainda existe? Diante dessa insaciável lei da procura e oferta, o valor imobiliário da cidade tomou proporções estratosféricas, perdeu-se o senso comum, a história e as tradições deixaram de existir, ou ficaram congeladas no tempo, que passou como uma retroescavadeira sobre as casas 
velhas, terrenos baldios, monumentos, praças, palacetes, casarões, ruas, avenidas, jardins, logradouros públicos. Quase nada restou, somente o Teatro Amazonas feito um criado mudo testemunhou, como sempre, o massacre. As famílias manauaras bateram em retirada do seu tradicional espaço urbano e, como os patos e marrecos no tempo de migração, sob a mira dos caçadores e para não entrar em extinção, fugiram para lugares seguros.

Ergueram-se prédios de apartamentos, construíram-se conjuntos habitacionais, surgiram novos bairros sem as mínimas condições de infra-estrutura urbana, o centro e os tradicionais bairros de Manaus foram abandonados e a cidade cresceu de costas para o rio; os antigos igarapés utilizados pela população transformaram-se em esgotos. Uma cultura perversa contra o patrimônio urbano e cultural manauara simplesmente ignorou o bom senso e o bom gosto.

Como de resto do país, a arquitetura da utopia modernista foi substituída pela contingência de um projeto político e econômico onde "a ordem unida" significava a sua essência. A monótona paisagem daqueles caixotes de concreto, onde a aridez dava a atmosfera sombria da vigilância política, ideológica. Ao inaugurar um desses "conjuntos habitacionais" o ditador-presidente Castelo Branco ficou pasmo diante do reduzido espaço e da qualidade do material construtivo, ele que conhecia como poucos a generosidade dos grandes espaços vazios, não se conteve e quebrou o protocolo:

"Mas isso parece casa para cachorros!".

Mas isso aconteceu no século passado, em outro milênio. E o que importa? A geração do Chico Bacurau é testemunha de todo o processo por que passou a humanidade faz cem anos, cá e lá, no balançar da rede está ele, imerso em suas lembranças abismais, surdo, quase cego, mas, como sempre, ator do seu próprio drama, para ele o tempo e o espaço são expressões imutáveis, o rio corre, aonde vão as suas águas, "dane-se". Aquelas edificações da Cidade Flutuante não significavam um mero desafio despudorado, mas habitações peculiares e tradicionais que sobrevivem ao avanço espetacular da cidade sobre a selva. A existência de um cotidiano diante e no meio das águas na região mais alagada do planeta exige sabedoria herdada dos ancestrais indígenas. Mesmo que muitos daqueles igarapés não existam mais, transformaram em esgotos fétidos ou mesmo em avenidas asfaltadas. As casas palafitas não mais ousaram constituir-se em Cidades Flutuantes, mas continuam a povoar a paisagem como favelas, moradias sob risco nos igarapés da cidade.

$\mathrm{Na}$ bacia do rio Negro, de janeiro a julho, as águas transbordam dos rios, lagos e riachos ou igarapés e inundam cerca de quinze mil quilômetros quadrados de floresta. Depois, começam a baixar até retornarem ao leito anterior no período de outubro a dezembro. À margem esquerda do rio Negro localiza-se Manaus, capital do estado do Amazonas. A cidade surgiu em 1669 a partir da construção do Forte de São José do Rio Negro e hoje é uma das mais dinâmicas e populosas metrópoles brasileiras, com mais de 1,5 milhão de habitantes. Uma 
ironia às idéias do século XVIII, em que as cidades com quinhentos mil habitantes eram desvios da natureza.

Quando Jean-Paul Belmondo foi filmado correndo entre as vielas da Cidade Flutuante, o Brasil vivia o frenesi do "novo", Brasília, a Nova Capital, o seu construtor Juscelino Kubitschek de Oliveira-JK, o Presidente Bossa Nova a qual, por sua vez, era a denominação da corrente musical brasileira que fazia fusão entre o ritmo das favelas com a batida sincopada nos apartamentos da zona sul carioca. O teatro, as artes plásticas, a poesia, assim como o cinema brasileiro, também carregavam a marca dessa tendência, o novo como agente da mudança e do moderno e é claro que Amazonas não poderia ficar de fora. Os líderes populistas amazonenses Plínio Coelho e Gilberto Mestrinho logo cunharam, como marca da sua administração, o slogan "Novo Amazonas", que tinha no restauro do Teatro Amazonas uma das suas principais obras. Diante dos milhares de andaimes que cercavam o Teatro, com ironia, Mestre Joaquim comentou:

"O governo do Novo Amazonas está encaixotando o Teatro para enviar à Nova Capital".

O filme O homem do rio traz o afeto que se encerra daqueles tempos, o Rio de Janeiro como uma cidade maravilhosa, onde o desafio do perigoso se confunde com aventuras, a cidade de Brasília, um ideal do modernismo futurista realizado no Novo Mundo e a cidade de Manaus, a paisagem exótica e selvagem da floresta amazônica, onde edificações de uma arquitetura ribeirinha bóiam, flutuam e apontam para um genuíno e possível morar no quintal da minha casa.

"O senhor está se metendo num assunto perigoso".

"Ah, é?"

"É, misturando fatos com ficção. Detenha-se apenas aos fatos" 11 .

Notas

1 Verdades e Mentiras (Ffor Fake, 1973), 86 minutos, França. Dir. Orson Welles. Rot. Orson Welles e Oja Palinkas. Com Orson Welles, Oja Kodar, Elmy de Hory, Clifford Irving, Edith Irving.

2 União do Vegetal é um Centro Espiritual, cujo objetivo é entrar em contato com a Força Superior e penetrar nos encantos da Natureza Divina, através de um chá alucinógeno chamado "cipó". Essa bebida sempre foi utilizada pelos povos indígenas, que a denominam "hauasca-caapi”. A partir do século XIX, com a chegada dos milhares de nordestinos à Amazônia, houve esse sincretismo religioso, quando um desses seringueiros, ao tomar esse chá, teve uma revelação e, partir de 1961, começou a reunir e a divulgar suas idéias. Hoje ele é o líder espiritual - Mestre Gabriel. No Acre, outro ex-seringueiro, o Mestre Raimundo Irineu Serra, fundou a doutrina do Santo Daime.

3 Meu tio (Mon oncle, 1958), 116 minutos, França. Dir. Jacques Tati. 
4 O homem do rio (L’homme de rio, 1964), 92 minutos, França. Dir. Philippe de Broca. Com Jean-Paul Belmondo e Françoise Dorleac.

5 A vida e paixão de Jesus Cristo - Da manjedoura à cruz(1902 e 1912). 115 minutos, França/ EUA. Dir. Feerdinand Zecca, Lucien Nonguet, Sidney Olcollf.

6 Acossado ( $\grave{A}$ bout de souffle,1960), 87 minutos, França. Dir. Jean-Luc Godard. Rot. J-L Godard e Françoise Truffaut. Com Jean-Paul Belmondo e Jean Seberg.

7 A Amazônia e a cobiça internacional, de Arthur César Ferreira Reis. Companhia Ed. Americana, 4를 ed., Rio de janeiro, 1972.

8 Ofim do rio (The End Of The River, 1947), 89 minutos, GB. Dir. Derek Twist. Com Bibi Ferreira e Sabu.

9 Os bandeirantes (Rio Negro, 1961), 92 minutos, França/ Itália. Dir. Marcel Camus. Com Raymond Lover, Lourdes Oliveira, Lea Garcia.

10 A lanterna na popa - Memórias, de Roberto de Oliveira Campos. Rio de Janeiro, Topbooks, 1994.

11 Oterceiro homem (The Third Man, 1949), GB/ EUA. Dir. Carol Reed. Rot. Graham Greene. Com Orson Welles, Joseph Cotten e Alida Valli.

RESUMO - O QUINTAL de minha casa trata do morar do homem na Amazônia, mas num recorte que inclui a vivência pessoal de um cineasta-documentarista. $\mathrm{Na}$ busca de personagens que possam relatar essa vivência, dois cartões-postais colorizados, especificamente da Cidade Flutuante, servem de mote para a empreitada.

ABSTRACT - THE BACKYARD of my home depicts men's life in the Amazon region, albeit in the manner of a cutout that includes the personal experience of a documentary filmmaker. Seeking out characters that might relate to this experience, two colorized postcards - specifically of the Floating City - become glosses of the undertaking.

Palavras-chave: Amazônia, Arquitetura, Manaus, Cidade Flutuante.

Keywords: Amazon, Architecture, Manaus, Floating City.

Aurélio Michiles é cineasta e dirigiu, entre outros documentários: Que viva Glauber! (1991), O cineasta da selva (1997), Teatro Amazonas e Gráfica utópica (2003). Atualmente, trabalha no documentário O quintal da minha casa e no filme-ficção Conde Stradelli.

Texto solicitado ao autor. Recebido e aceito para publicação em 10 defevereiro de 2005. 